Research Article

\title{
Molecular identification of methicillin resistance and virulence marker in staphylococcus aureus
}

\author{
N.D Gunawardena ${ }^{1}$, V. Thevanesam ${ }^{2}$, N Kanakaratne ${ }^{1}$, D.Abeysekera ${ }^{1}$, A Ekanayake ${ }^{2}$, \\ N Perera ${ }^{2}$
}

Sri Lanka Journal of Infectious Diseases 2012 Vol.2(2);18-29

DOI: http://dx.doi.org/10.4038/sljid.v2i2.4303

Key words: Methicillin-resistant Staphylococcus aureus; femB; mecA;

Panton-Valentine leukocidin; multiplex PCR

\begin{abstract}
Methicillin-Resistant Staphylococcus aureus (MRSA) is one of the major nosocomial pathogens in Sri Lanka. Life threatening infections with MRSA require rapid identification in order to initiate appropriate antimicrobial therapy. The Panton- Valentine leukocidin (PVL) is a virulence factor associated with severe MRSA infections for which routine detection is time consuming and dependent on the culture environment. ${ }^{1}$ The current study was therefore carried out to develop a rapid method for detection of MRSA and the presence of PVL gene using a multiplex polymerase chain reaction (mPCR). In the first phase of this study, results of conventional and molecular methods were compared for 43 clinical isolates of Staphylococcus aureus received from Teaching Hospital Peradeniya (THP). In the second phase, an additional 43 clinical samples obtained from patients were directly tested using $\mathrm{mPCR}$ and results including detection time of conventional and molecular methods compared. femB was negative in 7 of 43 isolates identified as $S$ aureus by conventional methods. Of the remaining 36 isolates, 12 were mecA positive with an oxacillin MIC of $>2 \mathrm{mg} / \mathrm{L}$. The mecA gene was detected in 10 isolates identified as MSSA by conventional testing. The $P V L$ gene was detected in 11 strains including both MRSA and MSSA. Direct MPCR on clinical samples was negative for all 3 genes in 15 of 43 samples from which $S$ aureus was isolated. Of the remaining 28 samples, 24 were $f e m B$ positive, 16 were mecA positive and 14 were positive for the $P V L$ gene. $\mathrm{mPCR}$ is helpful for the rapid identification of methicillin resistance and PVL production is staphylococci but less helpful in direct testing of samples.
\end{abstract}

${ }^{1}$ GENETECH Molecular Diagnostics \& School of Gene Technology, Colombo8, Sri Lanka

${ }^{2}$. Department of Microbiology, Faculty of Medicine, University of Peradeniya, Sri Lanka.

Address for correspondence: Dr. N.D Gunawardena. Institute for Research \& Development No.393/3, Lily Avenue, Off Robert Gunawardane Mawatha, Battaramulla 10120, Sri Lanka

Email : dinesha21@gmail.com 


\section{Introduction}

Methicillin-resistant Staphylococcus aureus (MRSA) is a specific strain of Staphylococcus aureus that has developed antibiotic resistance to all $\beta$-lactams. MRSA was first discovered in UK in 1961 and is now widespread, particularly in the hospital setting where it is commonly termed a superbug. ${ }^{2}$ In addition to MRSA traditionally being seen as a hospital-associated infection, in recent years community-acquired strains of MRSA (CA-MRSA) are being reported outside healthcare facilities throughout the world. These strains are often seen in healthy carriers - mostly among children, and often associated with skin and soft-tissue infections such as boils, styes and furunculosis. ${ }^{3}$ Some strains of CA-MRSA are particularly virulent and can cause life-threatening diseases such as pneumonia, mastitis, meningitis, osteomyelitis and endocarditis. ${ }^{4}$

Resistance to methicillin is mediated by the gene mecA which codes for a unique penicillin binding protein PBP2A with reduced affinity for $\beta$-lactam rings (the primary active-site of the $\beta$-lactam antibiotics) and is transmitted by a mobile genetic element termed staphylococcal cassette chromosome mec (SCCmec). ${ }^{5}$ In addition, some strains of $S$. aureus over-express $\beta$-lactamase (BORSA) and some strains of $S$. aureus, known as MODSA, which possess a modification of existing penicillin-binding proteins ( rather than acquisition of a PBP2A) appear to be resistant to oxacillin despite being mecAnegative. It is felt that reporting them as MRSA is probably an overcall of resistance. Therefore, PCR detection of mecA is considered as the 'gold standard' for staphylococcal methicillin resistance. ${ }^{2}$ Another gene, femB may further induce the expression of PBP2A for methicillin resistance in $S$. aureus and also acts as a specific species marker for identification of $S$. aureus in molecular assays. ${ }^{6}$

CA-MRSA strains tend to be more susceptible to non- $\beta$ lactam agents when compared with the hospital-acquired MRSA isolates. ${ }^{2}$ Many CA-MRSA have acquired the PantonValentine leukocidin (PVL) gene that produces a series of chemicals contributing to the invasiveness of these MRSA strains. ${ }^{5} \mathrm{PVL}$ is a multicomponent protein cytotoxin which belongs to the pore-forming toxin family that forms an octameric pore in the affected membranes of human polymorphonuclear neutrophils (PMNs), macrophages and monocytes. ${ }^{7}$ PVL is mainly associated with primary skin infections, especially furuncles, and with other deep-seated infections including necrotizing community-acquired pneumonia, pyomyositis, osteomyelitis and septic arthritis. ${ }^{7}$

In Sri Lanka, MRSA was first reported from the Teaching Hospital, Peradeniya (THP) in October $1989^{8}$ and has emerged as an important nosocomial pathogen over the past 20 years with up to $86 \%$ isolation rates in some hospitals. ${ }^{9}$ Infections with MRSA can give rise to increased morbidity and mortality, prolonged stay in hospital and increased cost of patient management. Isolation using selective media such as mannitol salt agar and detection of methicillin resistance by conventional antibiotic sensitivity testing and minimum inhibitory concentration (MIC) determination using dilution methods or E tests have been employed to detect MRSA. ${ }^{10}$ These methods require 2-3 days for completion. 
In addition, hetero-resistant strains may not always be detected using these methods as such isolates may express resistance only in some cells. ${ }^{11}$ More modern microbiological methods, such as DNA hybridization and the polymerase chain reaction (PCR) have focused on the detection of a DNA segment, mecA gene unique to MRSA. These assays are usually completed within one or two working days, thereby allowing a more rapid and accurate identification of methicillin resistance. ${ }^{11}$ Rapid detection and identification leads to early diagnosis and appropriate treatment which can significantly limit the duration and outcome of infection. The detection of PVL in S. aureus may also be helpful in explaining the severity of the infection. Further, aggressive therapy is required to treat $S$. aureus secreting PVL due to its severity of neutrophils, macrophages and tissue destruction thus warranting early detection. As PVL cytotoxin is difficult to detect by conventional methods, it is necessary to develop a molecular method that detects the PVL gene. ${ }^{1}$

The present study sought to develop a rapid in-house extraction method for simultaneous detection of $f e m B$, mecA and $P V L$ genes in clinical isolates and directly from patient samples using PCR.

\section{Material and methods}

\section{Specimens}

Forty-three clinical isolates identified as $S$. aureus by conventional laboratory methods collected from Teaching Hospital, Peradeniya (THP) between June and August 2007 were included in Phase 1 of the study.

In Phase 2, 43 patient samples [18 pus aspirates, 4 tracheal aspirates, 3 blood cultures, 1 liver abscess, 9 pus swabs, 3 umbilical swabs, 4 eye swabs and 1 ear swab] received between September to December 2007 from which S. aureus had been isolated and ABST performed in the routine microbiology laboratory-THP were included in the study.

A standard positive control of methicillin sensitive $S$ aureus (NCTC 6571) and a standard negative control of Escherichia coli (NCTC 10418) were included with each batch tested. ${ }^{12}$ Minimum inhibitory concentration (MIC) and mecA detection were used for susceptibility testing.

The MIC of oxacillin was determined using the agar dilution method. ${ }^{13}$ The antibiotic concentration causing completely inhibition of growth was taken as the end point. The results for $S$. aureus were reported as susceptible (methicillin sensitive $S$ aureus - MSSA) when $\mathrm{MIC}$ was $\leq 2 \mathrm{mg} / \mathrm{L}$ and resistant $(\mathrm{MRSA})$ when $>2 \mathrm{mg} / \mathrm{L} .{ }^{14}$

\section{Multiplex PCR for the detection of femB, mecA and PVL genes}

Sample homogenization and DNA extraction were performed by the methods described by Gunasekera,M.B. ${ }^{15}$ PCR assay was performed on purified genomic DNA extracted from clinical isolates as well as clinical specimens. Two sets of oligonucleotide primers 
were used to amplify mecA, femB and $P V L$ genes. Primer sequences published by Jonas et al $2002^{16}$ and Lina et al $1999^{1}$ were employed for the detection of susceptible genes. Multiplex PCR was carried out with 5 and $2.5 \mu \mathrm{l}$ of the extracted DNA in $25 \mu 1$ of PCR amplification mix consisting of $10 \mathrm{x}$ Buffer, $25 \mathrm{mM}$ of $\mathrm{MgCl}_{2}, 2.5 \mathrm{U}$ of Taq polymerase, $0.25 \mathrm{mM}$ of dNTP, $0.4 \mu \mathrm{M}$ of each primer; mecAl, mecA2, luk PV1 and luk PV2 and 0.5 $\mu \mathrm{M} \mathrm{femB1}$ and femB2. After amplification for 35 cycles $\left(45 \mathrm{~s}\right.$ of denaturation at $94^{\circ} \mathrm{C}, 45 \mathrm{~s}$ of annealing at $50^{\circ} \mathrm{C}$ and $60 \mathrm{~s}$ of extension at $72^{\circ} \mathrm{C}$ ), the amplicons were resolved by $1.5 \%$ agarose gel electrophoresis. (Fig.1 \& 2).

\section{Sensitivity of PCR assay}

To determine the lower limits of detection of MRSA, colony counts were performed on serial dilutions of a confirmed specimen from $10^{\circ}$ to $10^{-6} \mathrm{CFU} / \mu 1$ and parallel PCR was carried out on each dilution. PCR detection sensitivity was compared with the colony counts in order to determine the sensitivity of the mPCR assay. ${ }^{10}$

\section{Results}

In the first step of this study, all 43 clinical isolates were conventionally confirmed as $S$. aureus. Using PCR, the $f e m B$ gene was detected in 36 of the 43 isolates.

Out of the 43 isolates, 31 had MIC of methicillin $\leq 2 \mathrm{mg} / \mathrm{L}$ (MSSA) and 12 isolates were MRSA with values of 4 and $\geq 128 \mathrm{mg} / \mathrm{L}$. Using the PCR, all 12 (28\%) MRSA strains identified by conventional methods gave positive results for the mecA gene. However, 10 of the 31 isolates identified as MSSA were also mecA positive. All $7 \mathrm{femB}$ gene negative isolates were $m e c A$ positive (Figure 1).

\section{Figure1 Resolved DNA products from 7 of 43 S. aureus clinical isolates}

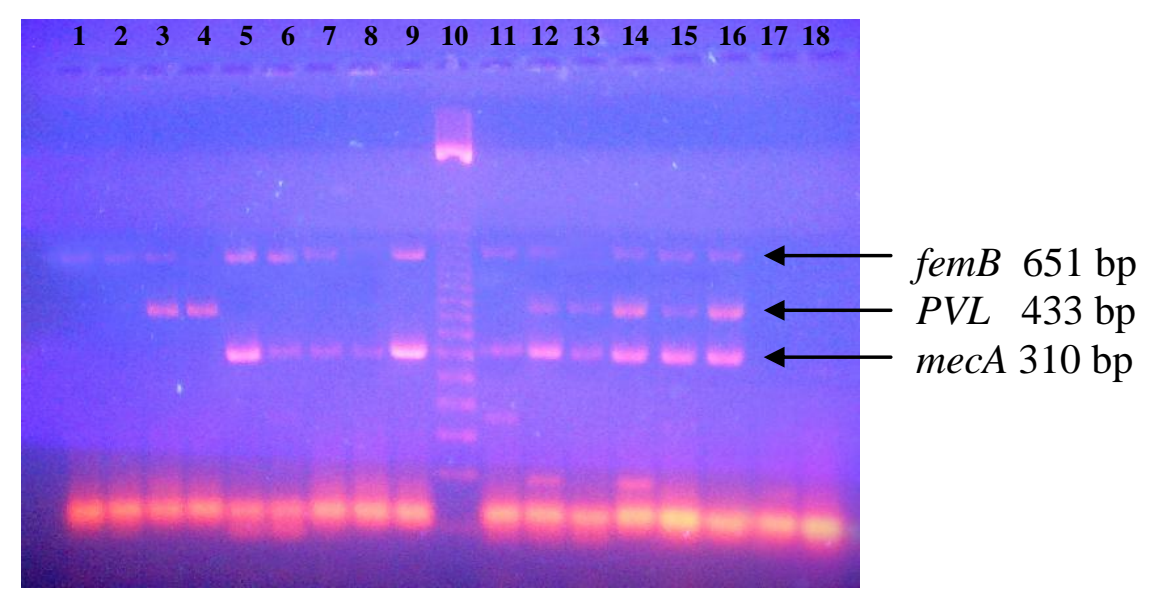

Figure 1: Agarose gel electrophoresis showing the PCR patterns of 651-bp, 433-bp and $310 \mathrm{bp}$ amplified genes of $f e m B, m e c A$ and $P V L$ respectively from clinical isolates with 
their DNA dilutions. Lanes 1 to 9 and 11 to 15 from clinical isolates; Lane 10, 50-bp ladder marker; Lane 16, positive control; Lanes 17 and 18, negative controls.

Eleven out of the 36 (30\%) S. aureus isolates demonstrated the PVL gene. Ten of them were MSSA and 1 was MRSA (Table 1).

Of the $S$. aureus isolated from the 43 clinical samples tested in the second phase of the study, 18 (42\%) were identified as MRSA by conventional disc diffusion testing with turn-around time of 48-72hrs. These 43 samples were directly examined for femB, mecA and $P V L$ genes using PCR (Figure 2). An appreciable number of samples (15/43) were negative when tested directly for all 3 genes (Table 2). Of the remaining 28 specimens, $f e m B$ gene was detected in 24(86\%). The mecA gene was detected in $14(78 \%)$ of the 18 samples from which MRSA was isolated. In addition, 2 samples from which MSSA was isolated were found positive for the mecA gene. Four samples which expressed the mecA gene were negative for $f e m B$ gene. Fourteen of the 43 samples were positive for the $P V L$ gene. 7 of them were MSSA and 7 were MRSA.

Figure 2 Resolved DNA products from 7 of 43 S. aureus clinical samples

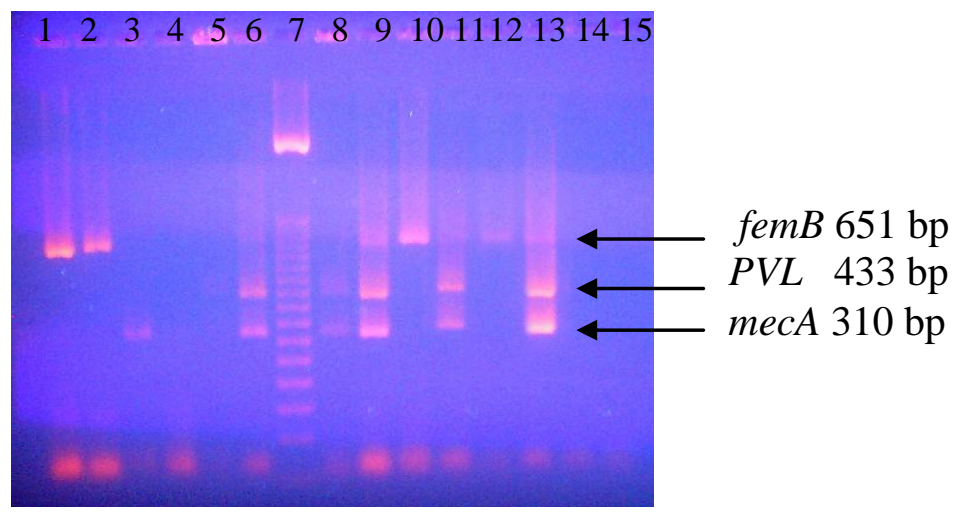

FIG.2. Agarose gel electrophoresis showing the PCR patterns of 651-bp, 433-bp and 310bp amplified genes of $f e m B$, mecA and $P V L$ respectively from direct samples with their DNA dilutions. Lanes 1 to 6 and 8 to 12 from direct samples; Lane 7, 50-bp ladder marker; Lane 13, positive control; Lanes 14 and 15, negative controls.

Direct testing by PCR required 4 hours for DNA preparation, PCR performance and detection of PCR products into the gel, in contrast with the 48-72 hours required for conventional testing.

\section{Discussion}

Detection of MRSA is important for patient care and appropriate utilization of infection control resources. In this evaluation, the molecular assay for MRSA detection was 
developed using both clinical isolates and patient samples and compared with conventional methods.

The current study demonstrated that $f e m B$ gene was not detectable in 7 of 43 isolates identified as $S$. aureus in the clinical laboratory (Table 1). Kobayashi et al ${ }^{17}$ reported that though $\mathrm{femB}$ gene is detectable only in $S$. aureus, an absence of $\mathrm{femB}$ gene does not mean that the isolate is not $S$. aureus. They have shown that up to 3\% of $S$. aureus strains can give negative results for the $f e m B$ gene even though they were positive for free coagulase and mannitol fermentation. Likewise, Mohanasoundaram and Lalitha ${ }^{11}$ found that $6(4 \%)$ of $150 \mathrm{MSSA}$ strains which gave positive free coagulase and mannitol fermentation tests were $f e m B$ negative. In contrast however, Sasaki et al ${ }^{18}$ reported that other coagulase positive staphylococci species share similar phenotypic characteristics of $S$. aureus and occasionally cause human infection. These 7 isolates were excluded from the analysis due to this uncertainty of identification.

Oxacillin MIC was determined for the 43 isolates of $S$. aureus using the agar dilution method. Using break point MIC, 31 strains with MIC $<2 \mathrm{mg} / \mathrm{L}$ were identified as MSSA and the remaining 12 isolates with $\mathrm{MIC}>2 \mathrm{mg} / \mathrm{L}$ as MRSA. Methicillin resistance is identified in the routine laboratory by disc diffusion and agar dilution methods which are simple and relatively cheap. Accurate determination of methicillin resistance in staphylococci by conventional tests is subject to variations in inoculum size, incubation time, medium $\mathrm{pH}$, and medium salt concentration. In addition, difficulties occur when organisms have their MICs near the break-point. It is in such instances that alternative methods are requested for identification of such strains. MecA gene detection by PCR is used in the identification of methicillin resistance in both $S$. aureus and coagulase negative staphylococci. The mecA gene was detected in all 12 isolates identified as MRSA by conventional methods.

In addition, 10 strains identified as MSSA using MIC were mecA positive. Presently, there is a considerable debate about appropriate break points, and reports of correlation between mecA status and methicillin or oxacillin MICs are conflicting. ${ }^{19,20}$ Nevertheless, isolates that possess the mecA gene show borderline resistance due to hyper-production of $\beta$-lactamases and are either heterogeneous or homogenous in their expression of resistance. With homogenous expression, virtually all cells express resistance when tested by standard in vitro tests. However, testing of hetero-resistant isolates may result in some cells appearing susceptible and others resistant. The clinical problem with such isolates is that during chemotherapy with $\beta$-lactam antibiotics, selection of strains with PBP-2A could result in MRSA infection. A precise identification is therefore essential for reliable treatment of S. aureus infection.

The PVL gene was expressed by 11 of $43(26 \%)$ S. aureus isolates. Ten of them were MSSA and 1 was MRSA. The PVL gene is encoded by the lukS-PV and lukF-PV genes, which are transmitted on a bacteriophage. PVL production has been described in MSSA and MRSA although lukS-PV and lukF-PV are not part of SCCmec. PVL is associated with severe necrotizing pneumonia and other soft tissue infections by destroying white cells. Lina et al reported that PVL is produced by $<5 \%$ of S. aureus strains. ${ }^{1}$ The 
presence of the $P V L$ gene in $S$. aureus strains provides a guide to the clinician that such strains may cause primary skin infections with or without necrotizing pneumonia, especially in young immune competent individuals. ${ }^{21}$ By testing for the $P V L$ gene in the same PCR reaction, it is possible to gain further insight into the added virulence of the MSSA or MRSA strain. This information is not available when using the conventional methods. It is assumed that PVL is secreted only by $S$. aureus.

Interestingly, 7 isolates with mecA gene and identified as $S$ aureus by conventional testing were not positive for $f e m B$ and $P V L$ genes. These isolates could be either coagulase negative staphylococci or another species of coagulase positive staphylococci. However, the $f e m B$ negative strains need further study.

Isolation of $S$. aureus from clinical samples takes 24-48 hours. Direct molecular testing of samples would provide more rapid results which in certain clinical situations would be useful, particularly in the management of an outbreak or early appropriate treatment of severe infections.

A further 43 clinical samples from which $S$. aureus was isolated were directly tested by PCR for $f e m B$, mecA and PVL genes. The FemB gene was detected in 24 of 43 samples of which $17(40 \%)$ were pus aspirates, $3(7 \%)$ blood cultures, $3(7 \%)$ tracheal aspirates and 1(2\%) liver abscess. As shown in Table 2, samples received as swabs appear to be insensitive for direct molecular testing with detection in only 2 such samples (7\%). Some possible reasons for the poor detection could be due to a low bacterial load which is below the required sensitivity of the PCR assay, cotton material in the swab acting as an inhibitor in the PCR assay or due to the storage condition of samples at room temperature for several days.

The mecA gene was detected in 14 of the 18 samples from which MRSA had been isolated by conventional methods. Four swabs which yielded MRSA using conventional isolation methods were negative for $f e m B$, mecA and $P V L$ genes.

Two samples from which MSSA was isolated were positive for the mecA gene. This highlights the issue, that disc diffusion or agar dilution testing performed in routine laboratories might fail to identify some strains of $S$. aureus which are MRSA as discussed previously.

Fourteen of the 28 samples tested directly were found to be positive for $P V L$ gene. PVL detected directly has diagnostic and therapeutic implications in severe PVL-related staphylococcal syndromes. It is noteworthy that none of the $f e m B$ negative samples contained the $P V L$ gene.

When comparing the assay times with conventional and PCR based methods, conventional testing of samples takes 3 to 4 days to confirm a MRSA. With an established PCR assay, confirmation of an isolate as MRSA is obtained in 4 hours which would be of clinical significance, particularly in patients with severe staphylococcal sepsis. 
This PCR assay is a rapid method which simultaneously identifies the $S$. aureus specific $f e m B$ gene, the mecA gene that confers methicillin resistance and the $P V L$ gene which determines the presence of PVL cytotoxin virulence factor. However, the relatively high negative findings when testing samples rather than isolates needs further study. This study demonstrated the presence of the PVL gene for the first time in Sri Lankan isolates of $S$. aureus. ${ }^{22}$ A subsequent study of $S$ aureus colonization of skin in patients with atopic dermatitis in a different locality of Sri Lanka also demonstrated the presence of the PVL gene in 5 of 8 MRSA strains tested, ${ }^{23}$ suggesting that these strains could be widely dispersed in the country. National surveillance of both hospital and community acquired MRSA and the distribution of the PVL genes is needed to plan strategies for control as well as empiric management of patients with severe staphylococcal sepsis.

\section{Conclusion}

In conclusion, this study shows that the conventional methods for detection of methicillin resistance viz., disc diffusion and agar dilution are time and labour consuming. Multiplex PCR is a simple, rapid and a good confirmatory test, but its use is limited to molecular diagnostic laboratories due to the need for technical expertise and cost.

\section{References}

1. Lina, G., Piedmont, Y., Gamot, F.G., Bes, M., Peter, M.O., Gauduchon, V.,Vandenesch, F. and Etienne, J.. Involvement of Panton-Valentine Leukocidinproducing Staphylococcus aureus in primary skin infections and pneumonia. Clinical Infectious Diseases. 1999; 29:1128-1132. doi:10.1086/313461

2. Hall, G.S., Shrestha, R. and Vogel, S.. Methicillin/Oxacillin-Resistant S. aureus (MRSA/ORSA): Laboratory Detection in 2004. BD Lab•O Microbiology News \& Ideas. 2004;15(2):1-3 No doi

3. Liu, Y.G. Molecular pathogenesis of Staphylococcus aureus infection. Pediatric Research. 2009; 65: (5) 71R-77R. doi:10.1203/PDR.0b013e31819dc44d

4. Yang, J.A., Park, D.W., Sohn, J.W. and Kim, M.J. Novel PCR- Restriction Fragment Length Polymorphism analysis for rapid typing of Staphylococcal Cassette Chromosome mec Elements. Journal of Clinical Microbiology. 2005;44: 236-238. doi:10.1128/JCM.44.1.236-238.2006

5. Berglund, C., Molling, P., Sjoberg, L. and Soderquist, B. Predominance of staphylococcal cassette chromosome mec (SCCmec) type IV among methicillinresistant Staphylococcus aureus (MRSA) in a Swedish country and presence of unknown SCCmec types with Panton-Valentine leukocidin genes. Journal of Clinical Microbiology and Infection. 2005;11: 447-456 doi:10.1111/j.1469-0691.2005.01150.x

6. Ehlert, K., Schroder, W. and Labischinski, H. Specificities of FemA and FemB for different glycine residues: FemB cannot substitute for FemA in staphylococcal peptidoglycan pentaglycine side chain formation. Journal of Bacteriology. 1997;179;7573-7576. No doi

7. McGrath, B., Rutledge, F. and Broadfield, E. Necrotizing pneumonia, Staphylococcus aureus and Panton-Valentine Leukocidin. Journal of Intensive Care Society. 2008;9:170-172. No doi 
8. Thevanesam, V., Wijeyawardana, W.L.K. and Ekanayake, E.W.M.

Methicillin resistant Staphylococcus aureus: the scale of the problem in a Shri Lankan hospital. Journal of Hospital Infection. 1994;26:123-127. doi:10.1016/01956701(94)90054-X

9. Song, J.H., Hsueh, P.R., Chung, D.R., Soo Ko, K., Kang, C.I., Ran Peck, K., Yeom, J.S., Kim, S.W., Chang, H.H., Kim, Y.S., Jung, S.I., Son, J.S., Man-kit So, T., Lalitha, M. K., Yang,Y., Huang, S.G., Wang, H., Lu, Q., Carlos, C.C., Perera, J.A., Chiu, C.H., Liu, J.W., Chongthaleong, A., Thamlikitkul, V., and Van, P.H., on behalf of the ANSORP Study Group: Spread of methicillin-resistant Staphylococcus aureus between the community and the hospitals in Asian countries: an ANSORP study. $J$ Antimicrob Chemother. 2011;66:1061-1069. doi:10.1093/jac/dkr024

10. Collee, J.C., Fraser A.G., Marmion, B.P. and Simmons, A. 2006 Viable count. In Mackie \& MaCartney Practical Medical Microbiology, $14^{\text {th }}$ edn. Churchill Livingstone, Elsevier, Chapter 48:849-850.

11. Mohanasoundaram, K.M. and Lalitha, M.K. Comparison of phenotypic versus genotypic methods in the detection of methicillin resistance in Staphylococcus aureus. Indian Journal of Medical Research. 2008;127:78-84. No doi

12. Cheesbrough, M. 2000. District Laboratory Practice In Tropical Countries Part 2. Cambridge University Press, UK, Chapter 7, 64-67.

13. Andrews, J. M. Determination of minimum inhibitory concentrations. The Journal of Antimicrobial Chemotherapy. 2001;48:5-16. doi:10.1093/jac/48.suppl_1.5

14. Andrews, J. M. (2011). BSAC Methods for Antimicrobial Susceptibility Testing. Version 10.2 May 2011.

15. Gunasekera, M.B. Rapid diagnosis of dengue virus infections in Sri Lanka by RTPCR- Solution hybridization technique. The Ceylon Medical Journal. 2000;48:1722. No doi

16. Jonas, D., Speck, M., Daschner, F. D. and Grundmann, H. Rapid PCR-Based Identification of Methicillin-Resistant Staphylococcus aureus from screening swabs. Journal of Clinical Microbiology. 2002;40:1821-1823. doi:10.1128/JCM.40.5.18211823.2002

17. Kobayashi, N., Wu, H., Kojima, K., Taniguchi, K., Urasawa, S., Uehara, N., Omizu, Y., Kishi, Y., Yagihashi, A. and Kurokawa, I. Detection of mecA, femA and femB genes in clinical strains of staphylococci using polymerase chain reaction. Epidemiology and Infection. 1994;113:259-266. doi:10.1017/S0950268800051682

18. Sasaki, T., Kikuchi, K., Tanaka, Y., Kamata, N.T. and Hiramatsu, K. MethicillinResistant Staphylococcus pseudintermedius in a Teaching Hospital. Journal of Clinical Microbiology. 2007; 45:1118-1125. doi:10.1128/JCM.02193-06

19. Brown, Derek F.J. Detection of methicillin/oxacillin resistance in staphylococci. The Journal of Antimicrobial Chemotherapy. 2001;48:65-70. doi:10.1093/jac/48.suppl_1.65

20. Cockerill, F.R., Wikler,M.A., Alder, J., Dudley, M.N., Eliopoulos, G.M., Ferraro, M.J., Hardy D.Y., Hecht, D.W., Hindler, J.A.,Patel, J.B., Powell, M., Swenson,J.M., Thomson R.B.,Traczewski, M.M.,Turnidge, J.D., Weinstein, M.P and Zimmer, B.L Performance standards for antimicrobial susceptibility testing: Twenty second informational supplement. Clinical and Laboratory Standards Institute. 2012; 32: (3). 
21. Yamasaki, O ., Kaneko, J., Morizane, S., Akiyama, H., Arata, J., Narita, S., Chiba, J.I., Kamio, Y and Iwatsuki, K The Association between Staphylococcus aureus strains carrying Panton-Valentine Leukocidin genes and the development of deepseated follicular infection. Clinical Infectious Diseases. 2005;40:382-385. doi:10.1086/427290

22. N. D. Gunawardena, V. Thevanesam, N. Kanakaratne,D. Abeysekera, A. Ekanayake, N. Perera, D. Ranaweera and D. Senevirathne. Molecular identification of methicillin resistance and virulence in Staphylococcus aureus.

Proceedings of the Peradeniya University Research Sessions, Sri Lanka.2008; 13: 238-241. No doi

23. P. L. R. Gomes, G. N. Malavige, N. Fernando, M. H. R. Mahendra, S. D. Kamaladasa, J. K. K. Seneviratne, D. H. Karunatilaka and G. S. Ogg .

Characteristics of Staphylococcus aureus colonization in patients with atopic dermatitis in Sri Lanka Clinical and Experimental Dermatology. 2011;36:(2)195200. doi:10.1111/j.1365-2230.2010.03962.x 
Table 1: Comparison of $f e m B, m e c A$ and $P V L$ genes with MIC of methicillin on clinical isolates identified as $S$. aureus $(n=43)$

\begin{tabular}{|c|c|c|c|c|c|}
\hline Sample ID & Site of collection & Fem $\mathrm{B}$ gene & Mec A gene & $P V L$ gene & MIL value \\
\hline Sall & Umbilical swab & $+v e$ & - & - & 0.25 \\
\hline Sal3 & Umbilical swab & $+\mathrm{ve}$ & - & - & 0.25 \\
\hline Sal 14 & Pus aspirate & $+v e$ & - & $+\mathrm{ve}$ & 0.25 \\
\hline Sal6 & Pus aspirate & $+\mathrm{ve}$ & - & - & 0.25 \\
\hline Sal7 & Pus aspirate & $+\mathrm{ve}$ & - & +ve & 0.25 \\
\hline Sal9 & Umbilical swab & $+\mathrm{ve}$ & - & - & 0.25 \\
\hline Sa26 & Pus aspirate & $+\mathrm{ve}$ & - & - & 0.25 \\
\hline Sa29 & Pus aspirate & $+\mathrm{ve}$ & - & - & 0.25 \\
\hline Sa32 & Umbilical swab & $+\mathrm{ve}$ & - & - & 0.25 \\
\hline Sa 36 & Eye swab & $+\mathrm{ve}$ & - & - & 0.25 \\
\hline Sa38 & Umbilical swab & $+\mathrm{ve}$ & - & - & 0.25 \\
\hline Sa 43 & Еar swab & $+\mathrm{ve}$ & - & - & 0.25 \\
\hline Sal & Eye swab & $+\mathrm{ve}$ & - & - & 0.5 \\
\hline Sa 2 & Pus aspirate & $+\mathrm{ve}$ & - & $+\mathrm{ve}$ & 0.5 \\
\hline Sall & Umbilical swab & $+\mathrm{ve}$ & - & - & 0.5 \\
\hline Sal2 & Umbilical swab & $+\mathrm{ve}$ & - & - & 0.5 \\
\hline Sal5 & Pus aspirate & $+\mathrm{ve}$ & - & - & 0.5 \\
\hline Sa23 & Pus aspirate & $+\mathrm{ve}$ & - & +ve & 0.5 \\
\hline Sa24 & Pus aspirate & $+\mathrm{ve}$ & - & $+\mathrm{ve}$ & 0.5 \\
\hline Sa 31 & Umbilical swab & $+\mathrm{ve}$ & - & - & 0.5 \\
\hline Sa 37 & Eye swab & $+\mathrm{ve}$ & - & - & 0.5 \\
\hline Sa 34 & Pus aspirate & $+\mathrm{ve}$ & $+\mathrm{ve}$ & $+\mathrm{ve}$ & 1.0 \\
\hline Sa 35 & Pus aspirate & $+\mathrm{ve}$ & $+\mathrm{ve}$ & $+\mathrm{ve}$ & 1.0 \\
\hline Sa39 & Pus aspirate & $+\mathrm{ve}$ & $+\mathrm{ve}$ & $+\mathrm{ve}$ & 1.0 \\
\hline Sa 4 & Umbilical swab & $+\mathrm{ve}$ & $+\mathrm{ve}$ & - & 2.0 \\
\hline Sa 7 & Blaod culture & $+\mathrm{ve}$ & $+\mathrm{ve}$ & $+\mathrm{ve}$ & 2.0 \\
\hline Sa 8 & Eye swab & - & $+\mathrm{ve}$ & - & 2.0 \\
\hline Sa 25 & Pus aspirate & - & $+\mathrm{ve}$ & - & 2.0 \\
\hline Sa27 & Umbilical swab & $+\mathrm{ve}$ & $+\mathrm{ve}$ & - & 2.0 \\
\hline Sa28 & Bland culture & - & $+\mathrm{ve}$ & - & 2.0 \\
\hline Sa 30 & Pus aspirate & $+\mathrm{ve}$ & $+v e$ & $+\mathrm{ve}$ & 2.0 \\
\hline $\mathrm{Sa} \mathrm{G}$ & Umbilical swab & - & $+\mathrm{ve}$ & - & 4.0 \\
\hline SaG & Pus aspirate & $+\mathrm{ve}$ & $+\mathrm{ve}$ & $+\mathrm{ve}$ & 128 \\
\hline Sa 3 & Pus swab & $+\mathrm{ve}$ & +ve & - & $>128$ \\
\hline Sa5 & Tracheal aspirate & $+\mathrm{ve}$ & $+\mathrm{ve}$ & - & $>128$ \\
\hline Sal8 & Pus aspirate & $+\mathrm{ve}$ & $+\mathrm{ve}$ & - & $>128$ \\
\hline Sa2D & Pus swab & $+\mathrm{ve}$ & $+\mathrm{ve}$ & - & $>128$ \\
\hline SaZl & Pus aspirate & - & $+\mathrm{ve}$ & - & $>128$ \\
\hline SaZ2 & Pus aspirate & $+\mathrm{ve}$ & $+\mathrm{ve}$ & - & $>128$ \\
\hline Sa 33 & Tracheal aspirate & $+\mathrm{ve}$ & $+\mathrm{ve}$ & - & $>128$ \\
\hline Sa 40 & Pus aspirate & $+\mathrm{ve}$ & $+\mathrm{ve}$ & - & $>28$ \\
\hline Sa 41 & Pus swab & - & $+\mathrm{ve}$ & - & $>128$ \\
\hline Sa 42 & Eye swab & - & $+\mathrm{ve}$ & - & $>128$ \\
\hline
\end{tabular}


Table 2: Comparison of $f e m B, m e c A$ and $P V L$ genes with ABST results on clinical samples $(n=43)$ from which $S$. aureus was isolated and identified by conventional methods

\begin{tabular}{|c|c|c|c|c|c|}
\hline Sample ID & Site of collection & Isalate characteristic & FemB gene & MecA gene & $P V L$ gene \\
\hline SA 14 & Pus aspirate & MSSA & $+v e$ & - & - \\
\hline SA 20 & Pus aspirate & MSSA & $+\mathrm{ve}$ & - & - \\
\hline SA 30 & Tracheal aspirate & MSSA & $+\mathrm{ve}$ & - & - \\
\hline SA 34 & Tracheal aspirate & MSSA & $+\mathrm{ve}$ & - & - \\
\hline SA 38 & Bload & MSSA & $+\mathrm{ve}$ & - & - \\
\hline SA 40 & Pus aspirate & MSSA & $+\mathrm{ve}$ & - & - \\
\hline SA 2 & Pus aspirate & MSSA & $+\mathrm{ve}$ & - & $+\mathrm{ve}$ \\
\hline SA 33 & Pus aspirate & MSSA & $+\mathrm{ve}$ & - & $+\mathrm{ve}$ \\
\hline SA 25 & Pus aspirate & MSSA & $+\mathrm{ve}$ & - & $+\mathrm{ve}$ \\
\hline SA 27 & Pus aspirate & MSSA & $+\mathrm{ve}$ & - & $+\mathrm{ve}$ \\
\hline SA 39 & Pus aspirate & MSSA & $+\mathrm{ve}$ & - & $+\mathrm{ve}$ \\
\hline SA 41 & Pus aspirate & MSSA & $+\mathrm{ve}$ & - & $+\mathrm{ve}$ \\
\hline SAI & Pus aspirate & MSSA & $+\mathrm{ve}$ & $+\mathrm{ve}$ & - \\
\hline SA 26 & Pus aspirate & MSSA & $+\mathrm{ve}$ & $+\mathrm{ve}$ & $+\mathrm{ve}$ \\
\hline SA 3 & Bland & MRSA & $+\mathrm{ve}$ & $+\mathrm{ve}$ & - \\
\hline SA 4 & Tracheal aspirate & MRSA & $+\mathrm{ve}$ & $+v e$ & - \\
\hline SA 8 & Pus aspirate & MRSA & $+\mathrm{ve}$ & $+\mathrm{ve}$ & - \\
\hline SA 5 & Bland & MRSA & $+\mathrm{ve}$ & $+v e$ & $+\mathrm{ve}$ \\
\hline SA 6 & Liver abscess & MRSA & $+\mathrm{ve}$ & $+v e$ & $+\mathrm{ve}$ \\
\hline SA 7 & Pus aspirate & MRSA & $+\mathrm{ve}$ & $+\mathrm{ve}$ & $+\mathrm{ve}$ \\
\hline SAID & Pus aspirate & MRSA & $+\mathrm{ve}$ & $+\mathrm{ve}$ & $+\mathrm{ve}$ \\
\hline SA II & Pus aspirate & MRSA & $+\mathrm{ve}$ & $+\mathrm{ve}$ & $+\mathrm{ve}$ \\
\hline SA IZ & Pus aspirate & MRSA & $+\mathrm{ve}$ & $+\mathrm{ve}$ & $+\mathrm{ve}$ \\
\hline SA ZI & Pus aspirate & MRSA & $+\mathrm{ve}$ & $+\mathrm{ve}$ & $+\mathrm{ve}$ \\
\hline SA 37 & Tracheal aspirate & MRSA & - & $+\mathrm{ve}$ & - \\
\hline SA 29 & Pus aspirate & MRSA & - & $+\mathrm{ve}$ & - \\
\hline SA 28 & Pus swab & MRSA & - & $+\mathrm{ve}$ & - \\
\hline SA 35 & Pus swab & MRSA & - & $+\mathrm{ve}$ & - \\
\hline SA 马 & Pus swab & MRSA & - & - & - \\
\hline SA 17 & Pus swab & MRSA & - & - & - \\
\hline SA 42 & Pus swab & MRSA & - & - & - \\
\hline SA Z2 & Umbilical swab & MRSA & - & - & - \\
\hline SA IG & Eye swab & MSSA & - & - & - \\
\hline SA I8 & Eye swab & MSSA & - & - & - \\
\hline SA 24 & Eye swab & MSSA & - & - & - \\
\hline SA 43 & Eye swab & MSSA & - & - & - \\
\hline SA 31 & Ear swab & MSSA & - & - & - \\
\hline SA IS & Pus swab & MSSA & - & - & - \\
\hline SA 23 & Pus swab & MSSA & - & - & - \\
\hline SA 32 & Pus swab & MSSA & - & - & - \\
\hline SA 36 & Pus swab & MSSA & - & - & - \\
\hline SAIB & Umbilical swab & MSSA & - & - & - \\
\hline SA I5 & Umbilical swab & MSSA & - & - & - \\
\hline
\end{tabular}

